\title{
Development of Reasoning Styles Scale
}

\author{
Volkan Duran ${ }^{1, *}$, Şener Şentürk ${ }^{2}$ \\ ${ }^{1}$ Department of Curriculum and Instruction, Gazi University, Ankarra, Turkey \\ ${ }^{2}$ Department of Curriculum and Instruction, Ondokuz Mayıs University, Samsun, Turkey
}

Copyright $(2019$ by authors, all rights reserved. Authors agree that this article remains permanently open access under the terms of the Creative Commons Attribution License 4.0 International License

\begin{abstract}
The aim of this study is to develop the reasoning style scale. The study was conducted with 300 undergraduates from different departments at Ondokuz Mayis University during the 2016-2017 academic year. Factor analysis was used to validate the structure of the scale. The KMO coefficient (783) and the Barlett test (p $<.05$ ) were found to be significant for the Kaiser-Meyer Olkin (KMO) and Barlett tests. The Cronbach's Alpha correlation coefficient used for the reliability coefficient was found for all of the scale $(\alpha=.784)$. As a result of the analyzes, "Reasoning Styles Scale" was developed as 5 likert and 4 sub-dimensions, and was found to be valid and reliable. The results of the exploratory factor analysis were applied to a sample of 109 students. Thus, $\chi^{2} / \mathrm{sd}$ was found to be 1,377 ; CFI value was found to be 943 ; GFI value was found to be, 906; IFI value was found to be, 945; TLI value was found to be ,930; RMSEA was found to be,059; RMR value was found to be ,061. As a result, a 12-item four-dimensional scale was obtained.
\end{abstract}

Keywords Style, Reasoning, Thinking Skills, Learning Styles

\section{Introduction}

Thinking and reasoning are used interchangeably each other. However, those concepts are distinct from each other in many ways. Firstly, reasoning is a more formal concept because it emphasizes the intellectual dimensions of thought. Secondly, it is related more systematic form of thinking. Thirdly, reasoning in essence is more abstract than thinking in which arguments should be based on premises, warrants so as to predict, defend or argue the assumptions at the core of each propositions. In this respect, thinking can be defined as the automatic and spontaneous reflection process of human intellect based on previous knowledge, memories and experiences. Elements of thinking are connotations, metacognition, epistemic cognition where it manifest itself in problem solving, creative thinking, critical thinking and decision-making processes in addition to expressions and daily communicational needs. Reasoning is more specific form of thinking in this respect where the elements of reasoning can be given as concepts, perspectives, assumptions, inferences, purposes, problems, information as data, facts, observations, experiences, implications and consequences $[18,19]$. For instance, solving a mathematical problem in an intuitive way where the individual see the pattern or the intrinsic rule of the problem just because his/her previous experiences or expertise can be given as an example of thinking process. However, solving or expressing the solution of the problem in a step by step manner based on arguments can be seen as an example of reasoning. For example, Toulmin's argument model can be given as a fair example which is stated that most arguments, regardless of the domain, have a structure that consists of six basic invariants: claim, data, modality, rebuttal, warrant and backing.

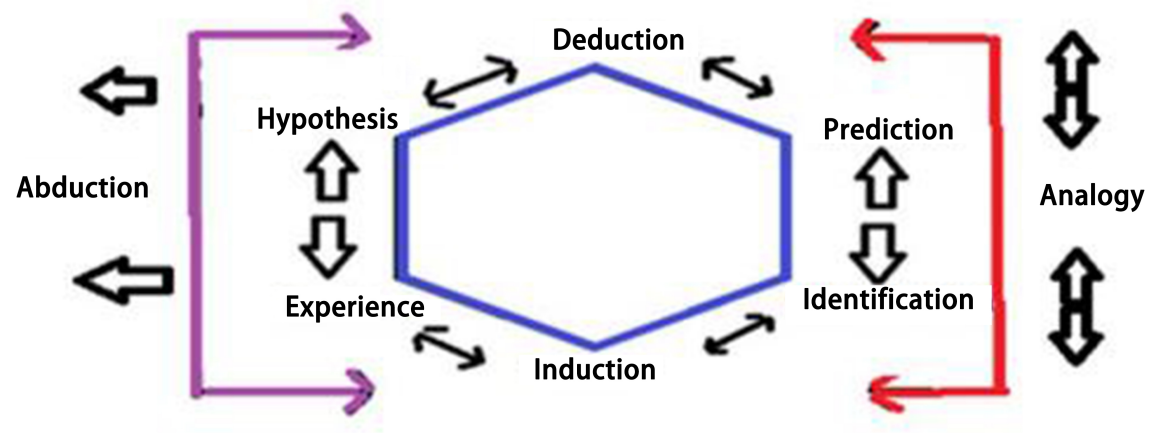

Figure 1. The structure of reasoning [6]. 
Reasoning skills can be classified as mainly inductive and deductive reasoning skills but there are also additional reasoning skills such as analogical, abductive based on the definitions or classifications. Induction is a way of making inferences about the unobserved object or items from the previous observation or experiences. It makes generalizations regarding the characteristics between objects and species with previous observations and experiences. It is used to formulate relationships and to formulate general statements and rules through limited observations of phenomenal models $[11,9]$. Deductive reasoning is the process of extracting a specific result from the general cases. Basically, it can be said that there is a kind of reasoning that makes the condition brought by the assumptions more explicit. Deductive reasoning is monotone and focused on certainty. The expressions such as all men are mortal can be applied to all people without exception. Deductions are mainly related with hypothesis and predictions whereas inductions are chiefly related with experiences and identifications. As for the abduction, it is simply defined as to infer the best explanation among the products of inductive and deductive reasoning and analogical reasoning is simply defined as to make analogy among the products of induction and deduction based on the resemblances of the characteristics of the concepts (Figure 2).

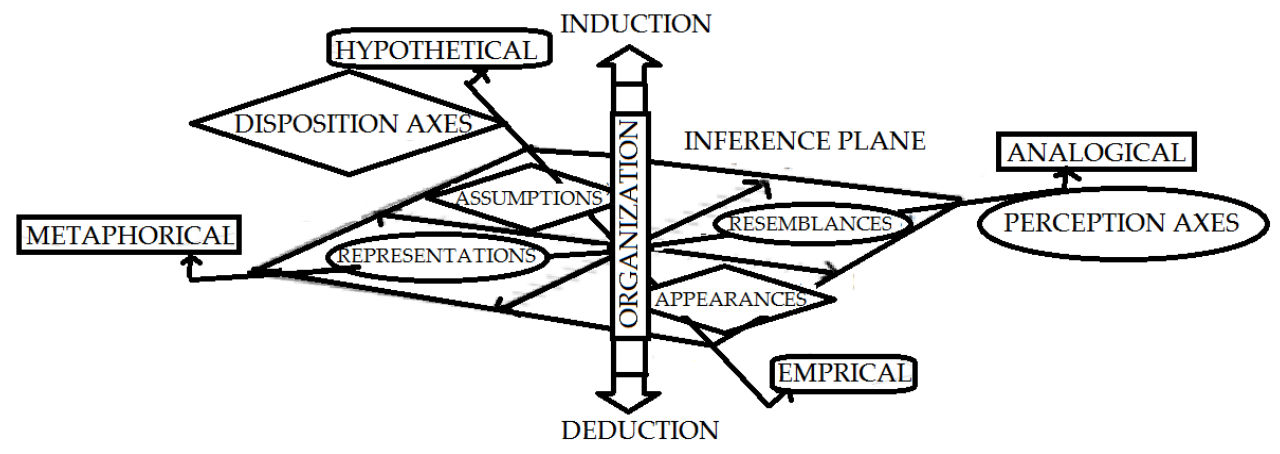

Figure 2. Reasoning styles model [6].

A style of reasoning is a pattern of inferential relations that are used to select, interpret, and support evidence for scientific results or specific phenomena [3]. Reasoning styles model is a model developed by Duran (2019), Duran and Özer (2017), Duran (2014) [6,7,8] classifying reasoning skills in the context of styles. According to this model there is a inference plane consists from four dimensions as representations, assumptions, resemblances and appearances. There are three axes in this model as perception axes, disposition axes and organization axes (Figure 3, 4).

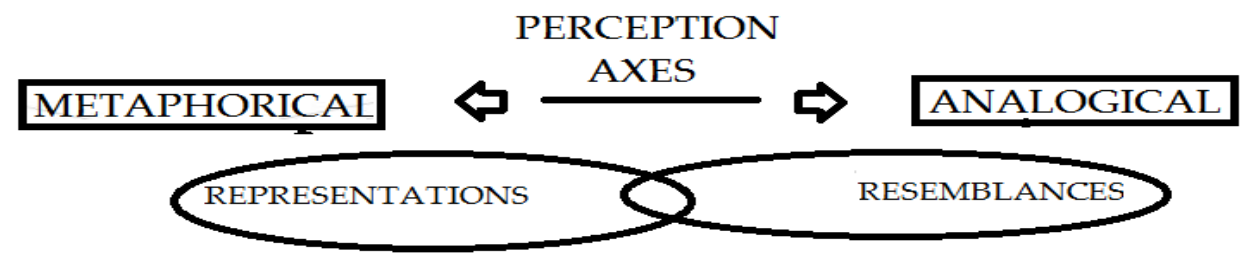

Figure 3. Perception axes

Perception axes include two dimensions as representations or resemblances (Figure 3). The reason why it is called as perception axes is that human cognition is fundamentally either based on sensations - outward orientation- or the ideas -inward orientation-. Therefore, inferences based on representations are defined as metaphorical whereas inferences based on the resemblances are analogical. Those two inferences patterns as metaphorical and analogical are located in the opposite corner of the inference plane because representations are the inferences based on the ideas created in an abstract ways whereas resemblances are mainly based on the data of the through sensations.

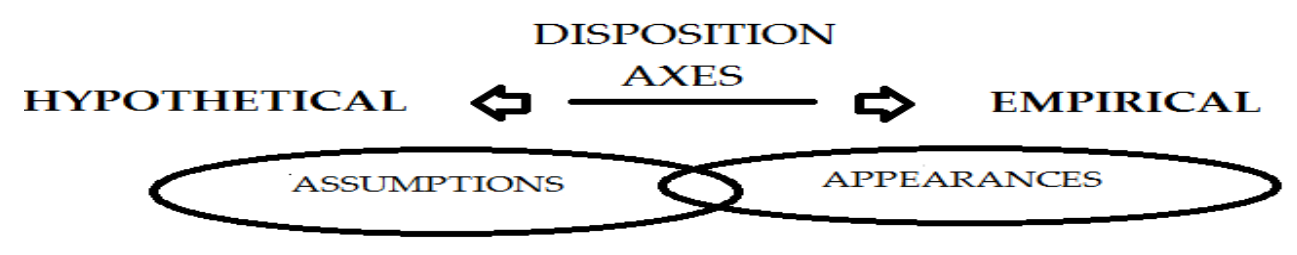

Figure 4. Disposition axes

Disposition axes include two dimensions as assumptions and appearances (Figure 4). The reason why it is called as 
disposition axes is that inferences can be structured fundamentally either based on appearances -outward orientation- or the assumptions -inward orientation-. Hence, inferences based on assumptions are defined as hypothetical whereas inferences based on the appearances are empirical. Those two inferences patterns as hypothetical and empirical are located in the opposite corner of the inference plane because assumptions are disposed based on the ideas created in an abstract ways whereas appearances are fundamentally based on the data of the through sensations. To sum up inference plane consists of empirical and analogical part because the analogical and empirical inferences are tangible and concrete and there is an opposite inference dimension as hypothetical and metaphorical because they are abstract and idea-oriented.

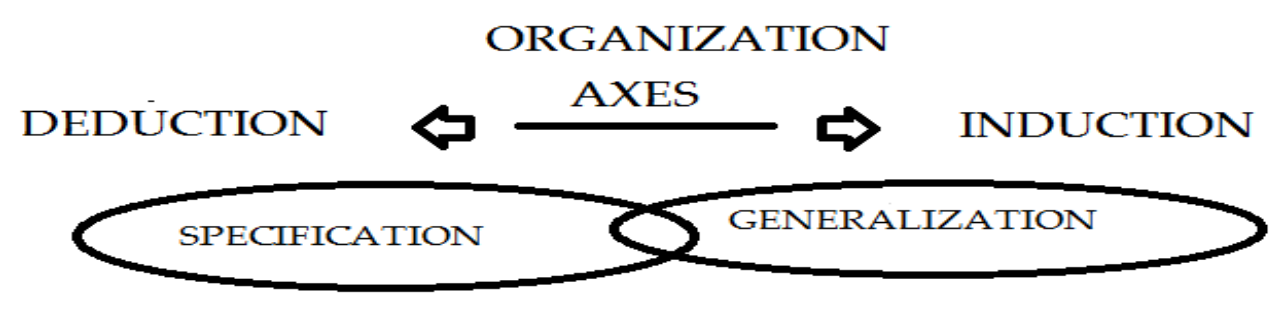

Figure 5. Organization axes

As for the dimension of organization of reasoning is considered as inductive and deductive where it is mentioned above in which reasoning can be mainly classified as two dimensions where induction is based on generalizations whereas deduction based on specification of the inferences (Figure 5).

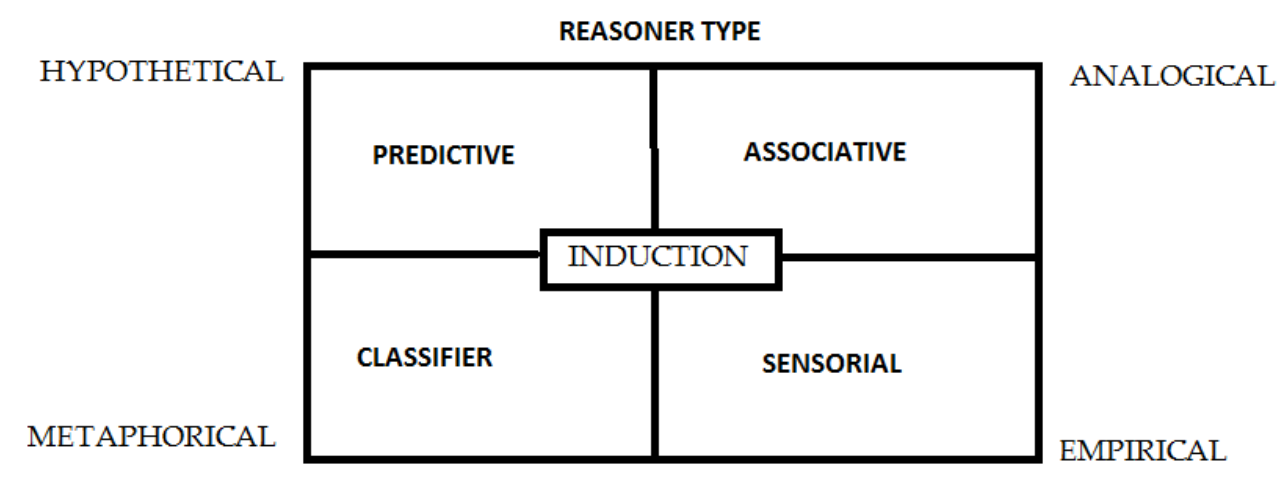

Figure 6. Reasoner type based on induction with inference plane

According the this model, individuals who are hypothetical-inductive are called as predictive reasoners, individuals who are empirical-inductive are called as sensorial reasoners, individuals who are metaphorical-inductive are classifiers individuals who are analogical-inductive are associative reasoners (Figure 6).

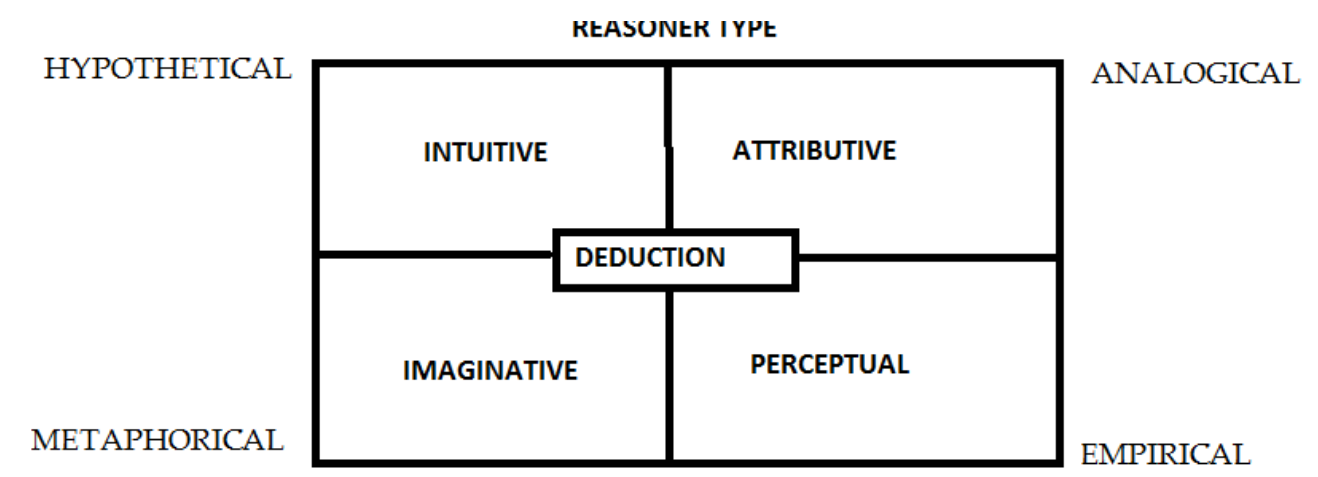

Figure 7. Reasoner type based on deduction with inference plane 
According the this model, individuals who are hypothetical-deductive are called as intuitive reasoners, individuals who are empirical-deductive are perceptual reasoners, individuals who are metaphorical-deductive are imaginative reasoners, individuals who are analogical-deductive are attributive reasoners (Figure7).

Although there are studies about learning styles and thinking styles in literature, it is seen that studies on reasoning styles in education are scarce and there is a gap in the literature on this issue in this regard. Reasoning style model is useful especially for designing the objectives and content of the curriculum as well as the evaluation and assessment part of it. It can be also useful for clarifying the different dimensions of reasoning and how the reasoning styles are related to other components of the didactic system $[1,12,13]$. Therefore, in this study, it is aimed to develop a valid and reliable, Likert-type measurement tool for reasoning styles of individuals. Furthermore, it is thought that the scale to be developed at the end of this study can be used in different courses in different disciplines, because the reasoning styles are at the core of every discipline.

\section{Materials and Methods}

The research was carried out to students in different departments in Samsun Ondokuz Mayss University in the $2016-2017$ academic year by screening model.

The sample of the study consisted of 300 students who had received undergraduate education, including Ondokuz May1s University Dentistry 14, Education 57, Faculty of Science and Literature 61, Theology 55, Communication 37, Economics 38, Engineering 38. The frequency and percentages of the students are 174 Female and 126 male, and the frequency and percentages of the departments they study are given in Table 1.

Table 1. Frequency and percentage distributions of student departments

\begin{tabular}{|c|c|c|}
\hline Departments & N & $\%$ \\
\hline Dentistry & 14 & 4,7 \\
\hline Education & 57 & 19 \\
\hline Faculty of Science and Literature & 61 & 20,3 \\
\hline Theology & 55 & 18,3 \\
\hline Communication & 37 & 12,3 \\
\hline Economics & 38 & 127 \\
\hline Engineering & 38 & 12,7 \\
\hline
\end{tabular}

Development of measurement Tool

This section describes the steps for improving the Reasoning Style Scale. The following phases were conducted to develop Reasoning Style Scale.

1. Literature Review: Firstly, the related literature was reviewed in detail. Based on the literature review, a total of 45 scale items were created because of the fact that the number of items in the draft scale should be three or four times or more than the actual desired one [17]. The scale was prepared as. Likert type where " $5=$ Strongly Agree", " $4=$ Agree," $3=$ Undecided, " $2=$ Disagree = and " $1=$ Strongly Disagree" and its range with is arranged as " $1,00-1,80=$ Strongly Disagree $1, " 1,81-2,60=$ Disagree", "2,61-3,40 = Undecided ", "3,41- 4,20 = Agree" and 4,21-5,00 = Strongly Agree" [16].

2. Content validity (expert opinion, conformity analysis): After the creation of the items, the itets were presented to the opinion of the Turkish experts and they were finalized by making necessary corrections in line with the suggestions of the experts. The scope validity of the items in accordance with the opinions given by the experts in this process was determined by the scope validity ratio developed by Veneziano and Hooper (1997; cited in Yurdagül, 2005). Expressions were evaluated by experts in terms of clarity, fluency, proper use of language, writing of various expressions and intelligibility criteria [14].

3. Application phase (pre-application, pilot application, general application): Three of 45 items were removed in accordance with the expert opinions as of the first application. (16-34-43). In the pilot phase, the scale was conducted to 52 students selected according to the appropriate sampling method. The final scale was conducted to 300 undergraduate students studying in different departments in Ondokuz Mayis University, which constitutes population group of this study.

4. Validability analysis (Factor analysis, KMO Barlet value)

In order to test the validity of the scale, the opinions of the experts about the subject of the scale were taken into account by Lawshe technique. Factor analysis was performed in order to determine the content validity of the scale and to determine the factor loads of the items. Kaiser-Meyer-Olkin (KMO) coefficient and Barlett Sphericity test were calculated to determine the appropriateness of the data before starting factor analysis. Finally, item-total, substance-residual and substance-discriminatory procedures were performed. [14].

5. Reliability analysis (Cronbach Alpha coefficient, Pearson Product Moment Correlation Coefficient)

The scale developed in order to determine students' styles of reasoning is Likert type scale. As the scores in the scale were between 1.00 and 5.00, it was accepted that the students' levels of participation in the propositions were lower as they approached 1.00 were higher as the scores approached to 5.00 .

The Cronbach Alpha coefficient was used to measure the reliability of the Likert-type scales. Pearson Product Moment Correlation Coefficient was calculated for all items, sub-dimensions and scale $[14,16]$. 


\section{Findings}

Table 2. KMO and Bartlett's Test

\begin{tabular}{|c|c|c|}
\hline $\begin{array}{c}\text { Kaiser-Meyer-Olkin } \\
\text { (KMO) }\end{array}$ &, 783 \\
\hline & Chi-Square Value & 1448,054 \\
\hline $\begin{array}{c}\text { Barlett's Test of Sphericity } \\
\text { (BTS) }\end{array}$ & Degree of freedom & 253 \\
\hline & $\mathbf{p}$ &, 000 \\
\hline
\end{tabular}

In order to determine the sub-factors and reliability level of the measurement tool, the data loss was checked firstly. After confirming that there is no missing or incorrect data, Kaiser-Mayer-Olkin (KMO) and Barlett's Test of Sphericity (BTS) tests were performed to measure the adequacy of the sample used in the study. Kaiser-Meyer-Olkin (KMO) and Bartlett values were determined in the factor analysis process; The principal components analysis was carried out and the varimax rotation was performed. The KMO test result of the measurement instrument was 0.783 . The findings of KMO and Bartlett's Test are given in Table 2.

In the KMO statistics, the values between " $0.50-0.70$ " regarded as moderate the values between "0.70-0.80 regarded as good, the values between " $0.80-0.90$ " regarded as very good and the values between " 0.90 and above" regarded as excellent [10] and the sample size and data obtained in this study is appropriate and sufficient for the selected analysis (0.78). The significance of the Bartletttedirs values $(\mathrm{p}<.005)$ also supports the hypothesis that the data comes from the multivariate normal distribution. This value which is statistically significant as a result of Bartlettmeks Test Sphericity analysis ( $\mathrm{B}=$ $1448.05, \mathrm{p}<0.005)$ indicates that the sample is sufficient and the data shows normal distribution (Geçgil and Tikici,
2015). Thus, it can be said that the factor analysis on these data gives reliable results. Due to the very small number of substances being loaded into some factors related to the substances of the measuring instrument, the scree plot is shown in Figure 8, which shows the factor structure of the Reasoning Styles Scale.

Although it seems that the scale has two main factors, considering the model of reasoning styles from here, it is thought that the scale may consist of 4 factors. In order to make factor selection, Kaiser Normalization and Varimax methods have been analyzed [10]. Although the factor load value of a substance should not be less than .30, there are also theorists who argue that this magnitude should be .40 (Çokluk et al., 2012: 194). In this study, in varimax rotation, the items having a factor loading of 0,40 as the lower cut-off point of the factor loadings were processed and the items with a factor load of less than 0,40 were neglected. Therefore, in the general practice, the item load 9-23-36-39-8-12-40-44 was removed due to the fact that it remained below 40. According to these findings, it was determined that the four factors that emerged at the end of the analysis explained the total variance and $42 \%$ of the variance together. According to Kline, this value is higher than $40 \%$ [5]. The variance amounts explained by the factors were $19.947 \%$ for the first factor, $9.264 \%$ for the second factor, $7.740 \%$ for the third factor and $5.854 \%$ for the fourth factor. The higher the variance rates obtained at the end of the factor analysis, the stronger the factor structure of the scale. It is not possible to reach very high variance rates in social sciences, and variance rates varying from $40 \%$ to $60 \%$ are accepted as sufficient [15].. The results of Varimax vertical rotation analysis to determine the distribution of substances to factors are presented in the table below.

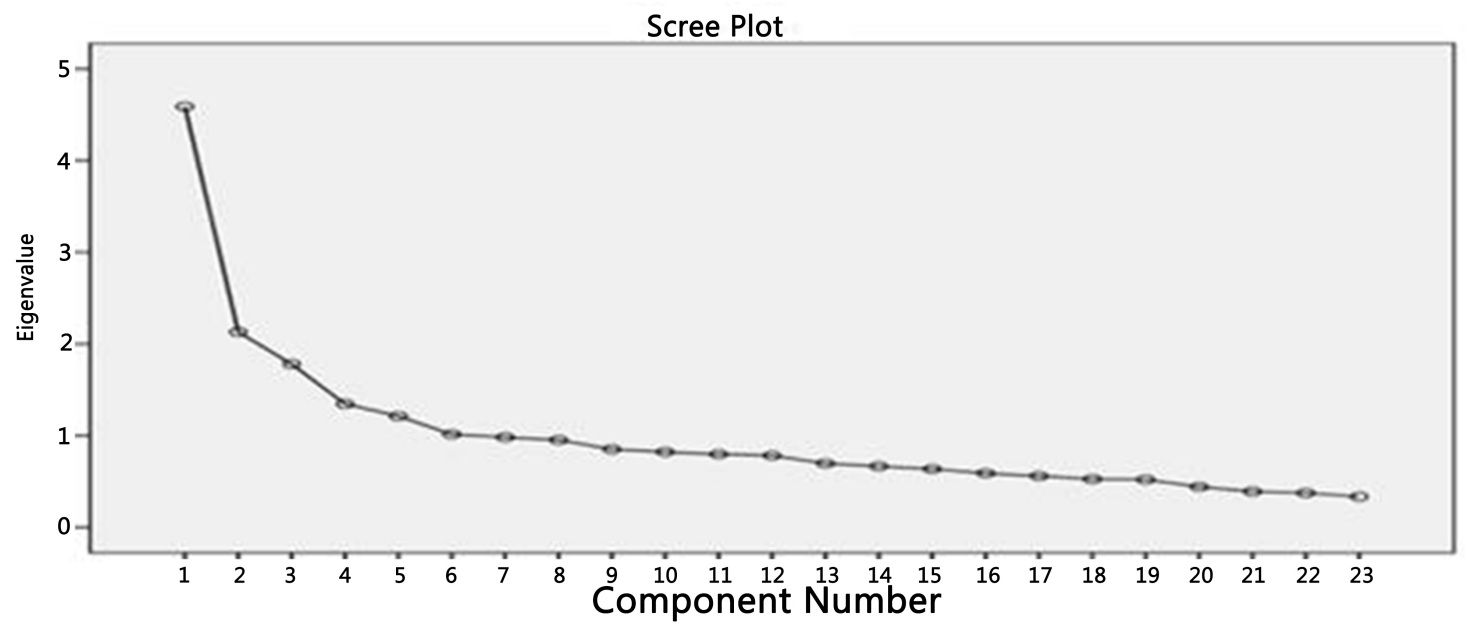

Figure 8. Scree plot 
Table 3. Total Variance

\begin{tabular}{|c|c|c|c|c|c|c|c|c|}
\hline \multirow[b]{2}{*}{ Component } & \multicolumn{3}{|c|}{ Initial Eigenvalues } & \multicolumn{3}{|c|}{ Extraction of Sums of Square Loads } & \multicolumn{2}{|c|}{ Rotating Square Totals } \\
\hline & Total & Variance $\%$ & $\begin{array}{c}\text { Cumulative } \\
\%\end{array}$ & Total & Variance $\%$ & $\begin{array}{c}\text { Birikimsel } \\
\%\end{array}$ & Total & Variance $\%$ \\
\hline 1 & 4,588 & 19,947 & 19,947 & 4,588 & 19,947 & 19,947 & 3,989 & 17,345 \\
\hline 2 & 2,131 & 9,264 & 29,211 & 2,131 & 9,264 & 29,211 & 2,103 & 9,144 \\
\hline 3 & 1,780 & 7,740 & 36,951 & 1,780 & 7,740 & 36,951 & 1,973 & 8,577 \\
\hline 4 & 1,347 & 5,854 & 42,806 & 1,347 & 5,854 & 42,806 & 1,780 & 7,740 \\
\hline 5 & 1,213 & 5,273 & 48,079 & & & & & \\
\hline 6 & 1,015 & 4,412 & 52,491 & & & & & \\
\hline 7 & ,982 & 4,271 & 56,762 & & & & & \\
\hline 8 & ,952 & 4,140 & 60,902 & & & & & \\
\hline 9 &, 851 & 3,702 & 64,604 & & & & & \\
\hline 10 & ,822 & 3,574 & 68,178 & & & & & \\
\hline 11 & ,797 & 3,464 & 71,643 & & & & & \\
\hline 12 & ,783 & 3,404 & 75,047 & & & & & \\
\hline 13 & ,697 & 3,030 & 78,077 & & & & & \\
\hline 14 & ,666 & 2,894 & 80,971 & & & & & \\
\hline 15 & ,637 & 2,769 & 83,740 & & & & & \\
\hline 16 &, 589 & 2,562 & 86,302 & & & & & \\
\hline 17 & ,559 & 2,431 & 88,733 & & & & & \\
\hline 18 &, 527 & 2,292 & 91,025 & & & & & \\
\hline 19 &, 521 & 2,265 & 93,290 & & & & & \\
\hline 20 & ,442 & 1,922 & 95,212 & & & & & \\
\hline 21 & ,391 & 1,698 & 96,910 & & & & & \\
\hline 22 &, 376 & 1,634 & 98,544 & & & & & \\
\hline 23 &, 335 & 1,456 & 100,00 & & & & & \\
\hline
\end{tabular}

In order to determine the factor pattern of the study, varimax was chosen as the principal component analysis and the rotation method was used as the rotation method. Considering the distribution of items by using Varimax Steep Rotation Technique, it was found that the scale was collected in 4 factors having the eigenvalues larger than 1 , all items had acceptable load values (the lowest item load value was 0.480 ; the highest item load value was 0.726 ).
In addition, exploratory factor analysis was applied to ensure the construct validity of the scale. As a result of exploratory factor analysis, factor load weights of 19 items were found to be low. Therefore, some items were excluded from the measurement tool by the researchers to limit the factor number of the scale and to increase the reliability level. 
Table 4. Transformed Components Matrix after Factor Analysis

\begin{tabular}{|c|c|c|c|c|}
\hline & 1 & 2 & 3 & 4 \\
\hline Item 4 & .712 & & & \\
\hline Item 2 & .673 & & & \\
\hline Item 28 & .645 & & & \\
\hline Item 1 & .643 & & & \\
\hline Item 3 & .627 & & & \\
\hline Item 5 & .600 & & & \\
\hline Item 31 & .583 & & & \\
\hline Item 7 & .562 & & & \\
\hline Item 45 & .512 & & & \\
\hline Item 6 & .480 & & & \\
\hline Item 26 & & .700 & & \\
\hline Item 17 & & .564 & & \\
\hline Item 25 & & .542 & & \\
\hline Item 38 & & .524 & & \\
\hline Item 24 & & .514 & & \\
\hline Item 20 & & & .726 & \\
\hline Item 41 & & & .695 & \\
\hline Item 10 & & & .588 & \\
\hline Item 15 & & & .526 & \\
\hline Item 35 & & & & .678 \\
\hline Item 12 & & & & .612 \\
\hline Item 37 & & & & .559 \\
\hline Item 30 & & & & .517 \\
\hline
\end{tabular}

As shown in Table 4 and Table 5, a scale havingg a total of 23 items having 4 factors where the first factor having 10 items (1-2-3-4-5-6-7-28-31-45); the second factor consists of 5 items (Articles 17-24-25-26-38); the third factor is 4 items (10-15-20-41); the fourth factor consists of 4 items (items 12-30-35-37). Sub-dimensions were formed and named by examining the items in each factor. In this context, the first subdimension is named as the Induction sub-dimension; the second dimension is named as sub-dimension Hypothetical sub-dimension; third sub-dimension is named as as Emprical sub-dimension; and the fourth sub-dimension is named as deductive sub-dimension (Table 6, Table 7, Table 8).
Table 5. Sub-dimensions determined as a result of factor analysis

\begin{tabular}{|c|c|c|}
\hline Factors & Number of Items & The Item Numbers \\
\hline 1 & 10 & $1-2-3-4-5-6-7-28-31-45$ \\
\hline 2 & 5 & $17-24-25-26-38$ \\
\hline 3 & 4 & $10-15-20-41$ \\
\hline 4 & 4 & $12-30-35-37$ \\
\hline
\end{tabular}

In Table 6, the statistical values of the total questions are presented. These values are supposed to be generally not negative and are expected to be greater than 0.30 . Items that do not comply with this rule were removed from the scale. However, since confirmatory factor analysis will be performed, the items were not excluded from the scale. 
Table 6. Descriptive Values Related to Items Determined as a Result of Factor Analysis

\begin{tabular}{|c|c|c|c|c|c|}
\hline & $\begin{array}{c}\text { Average Values When } \\
\text { Item Deleted }\end{array}$ & $\begin{array}{c}\text { Variance When Item } \\
\text { Deleted }\end{array}$ & $\begin{array}{c}\text { Total } \\
\text { Correlation } \\
\end{array}$ & $\begin{array}{l}\text { Multi-Squared } \\
\text { Correlation }\end{array}$ & $\begin{array}{c}\text { Cronbach's Alpha When } \\
\text { Item Deleted }\end{array}$ \\
\hline Item 1 & 73,5749 & 90,882 &, 421 & ,399 & ,775 \\
\hline Item2 & 73,4549 & 91,033 &, 470 & ,410 & ,773 \\
\hline Item 3 & 73,5549 & 90,319 &, 474 & ,397 & ,772 \\
\hline Item4 & 73,6316 & 90,185 &, 509 & ,446 &, 770 \\
\hline Item5 & 73,8016 & 91,636 & ,480 & ,329 & ,773 \\
\hline Item6 & 73,9882 & 93,769 & ,286 & ,224 & ,783 \\
\hline Item7 & 73,6482 & 92,384 & ,380 &, 319 & ,777 \\
\hline Item 28 & 73,3349 & 91,044 & ,436 & ,437 & ,774 \\
\hline Item31 & 73,5549 & 90,721 & ,428 &, 341 & ,774 \\
\hline Item 45 & 73,9349 & 89,697 &, 470 & ,279 & ,772 \\
\hline Item 17 & 74,4916 & 98,536 & ,066 & ,187 & ,794 \\
\hline Item 24 & 74,1282 & 94,434 & ,281 & ,224 & ,783 \\
\hline Item 25 & 74,0249 & 93,397 & ,302 & ,229 & ,782 \\
\hline Item 26 & 73,9049 & 94,830 &, 307 & ,279 & ,781 \\
\hline Item38 & 74,1816 & 94,666 & ,263 & ,214 & ,784 \\
\hline Item 10 & 73,8867 & 92,984 &, 365 &, 259 & ,778 \\
\hline Item 15 & 74,1416 & 92,983 &, 367 & ,263 & ,778 \\
\hline Item 20 & 74,1249 & 94,389 & ,303 & ,326 & ,782 \\
\hline Item41 & 74,0149 & 94,130 & ,300 &, 340 & ,782 \\
\hline Item 12 & 74,4049 & 94,818 & ,261 &, 230 &, 784 \\
\hline Item30 & 74,6482 & 95,675 &, 174 & ,196 & ,790 \\
\hline Item35 & 74,4416 & 96,429 &, 160 & ,195 & ,790 \\
\hline Item37 & 74,9349 & 96,046 & 157 & ,262 & ,791 \\
\hline
\end{tabular}

Pearson Product Moment Correlation analysis was performed to determine whether there was a significant relationship between the factors. These results show that all factors are in the same structure because there is a low but significant correlation among the dimensions of the scale. If all the dimensions are highly correlated, they couldn't be regarded as separate dimensions. However, if there was no correlation among them, it indicates they are totally distinct from each other. Low positive correlation indicates those dimensions are related in each other in a coherent structure.

Table 7. Pearson Product Moment Correlation Analysis Results for Determining Relationships Between Factors

\begin{tabular}{|c|c|c|c|}
\hline & Hypothetical & Empirical & Deduction \\
\hline Induction & ${ }_{v} 241^{* *}$ & ${ }_{v} 320^{* *}$ & ${ }_{, 107^{* *}}$ \\
\hline Hypothetical & & ${ }_{*} 206^{* *}$ & ${ }^{* 143^{* *}}$ \\
\hline Empirical & & & ${ }_{.} 265^{* *}$ \\
\hline
\end{tabular}

As a result of the reliability studies, Cronbach Alpha internal consistency coefficient of the whole scale was determined as .788. At the end of these analyzes the Cronbach Alpha reliability coefficients of the sub-factors were below .350. Low correlations between variables suggest that formative measurement models may be more appropriate for scales having more than 1 factors. The measurement model is expressed in two different forms as reflective and formative. In the reflective structure, the direction of causality is true of the variables observed from the implicit variable. The variables observed in this structure have the same or similar content. In the formative model, the observed variables do not have to have the same or similar content, and the direction of causality is from the observed variables to the implicit variable. In the formative measurement model, variables determine the concept. Cause-and-effect relationship emerges from variables. Therefore, Cronbach Alpha reliability coefficient for the 
scale is acceptable in this regard $[2,18]$

\section{Confirmatory Factor Analysis}

The 23-item scale was applied to 109 students from different departments of Ondokuz Mayis University. Confirmatory factor analysis (CFA) was used to test the construct validity of the original structure of the scale.. In the first analysis, $\chi^{2} / \mathrm{sd}$ is less than 3 , indicating that the model is in good agreement as a result of the analysis. However because the CFI and GFI values are above .90 and the RMSEA value is between 0.05 and 0.08 , and it can be said that the compatibility of the model is not sufficient given as in Table 8 [4].

Table 8. Results of the first confirmatory factor analysis of the reasoning styles scale

\begin{tabular}{|c|c|}
\hline$\chi^{2} / \mathrm{sd}$ & 2,454 \\
\hline CFI &, 574 \\
\hline GFI &, 716 \\
\hline RMSEA &, 116 \\
\hline
\end{tabular}

As can be seen, the values were not sufficient and 5'th item in induction dimension having the lowest value, the standard regression weight as , 072, 22'th item in deduction dimension having the standard regression weight, as .182 and 10'th item in Empirical dimension having the standard regression weight as .000 were removed in the analysis. The following values were obtained again as follows:

Table 9. Results of the second confirmatory factor analysis of the reasoning styles scale

\begin{tabular}{|c|c|}
\hline$\chi^{2} / \mathrm{sd}$ & 2,343 \\
\hline CFI &, 665 \\
\hline GFI &, 759 \\
\hline RMSEA &, 111 \\
\hline
\end{tabular}

As can be seen, the values were not sufficient and 2 'th item in induction dimension having the lowest value, the standard regression weight as ,202, 6'th item in induction dimension having the standard regression weight, as ,273 and 13'th item in hypothetical dimension having the standard regression weight as ,329, 16'th item in empirical dimension having the standard regression weight, as ,283, removed in the analysis. The following values were obtained again as follows:

Table 10. Results of the third confirmatory factor analysis of the reasoning styles scale

\begin{tabular}{|c|c|}
\hline$\chi^{2} / \mathrm{sd}$ & 2,169 \\
\hline CFI &, 783 \\
\hline GFI &, 823 \\
\hline RMSEA &, 104 \\
\hline
\end{tabular}

As can be seen, the values were not sufficient and 4'th item in induction dimension having the standard regression weight as ,341, 3'th item in induction dimension having the standard regression weight, as ,341 and 11'th item in hypothetical dimension having the standard regression weight as ,498, 7'th item in Empirical dimension having the standard regression weight, as ,560. were removed in the analysis. In addition, modification are done between the 8'th and 9'th items in induction dimension and between the $18^{\prime}$ th and $17^{\prime}$ th items in empirical dimension. The following values were obtained again as follows:

Table 11. Results of the last confirmatory factor analysis of the reasoning styles scale

\begin{tabular}{|c|c|l|}
\hline$\chi^{2} / \mathrm{sd}$ & 1,377 & $\begin{array}{l}\text { A value of } 2 \text { or less indicates the goodness of } \\
\text { the model. }\end{array}$ \\
\hline CFI &, 943 & $\begin{array}{l}\text { Values greater than } 0.95 \text { indicates the model fit } \\
\text { is very good. }\end{array}$ \\
\hline GFI &, 906 & $\begin{array}{l}\text { The GFI values greater than } 0.90 \text { indicates that } \\
\text { the model is a good model. }\end{array}$ \\
\hline IFI &, 945 & $\begin{array}{l}\text { Values between } 90 \text { and } 0.95 \text { indicates that the } \\
\text { model is acceptable. }\end{array}$ \\
\hline TLI &, 930 & $\begin{array}{l}\text { The value between } 0.90 \text { and } 0.95 \text { indicates the } \\
\text { acceptability of the model. }\end{array}$ \\
\hline RMSEA &, 059 & $\begin{array}{l}\text { If it is below 08, it is an acceptable goodness } \\
\text { value. }\end{array}$ \\
\hline RMR &, 061 & $\begin{array}{l}\text { The value above } 0.50 \text { indicates acceptable } \\
\text { model-data compliance. }\end{array}$ \\
\hline
\end{tabular}

The Cronbach Alpha internal consistency coefficient of the whole scale was found to be 670 . At the end of these analyzes, the Cronbach Alpha reliability coefficients of the sub-factors were; 0.674 for Factor-1, 0.799; For Factor-2, 0.760 for Factor-3 and 0.647 for Factor-4. When the exploratory factor analysis is repeated, it is seen that there is a four-factor structure explaining $68,085 \%$ of the variance.

As a result of confirmatory factor analysis, standardized regression weights of items can be given as follows.

Table 12. Standardized regression weights of items

\begin{tabular}{|c|c|c|c|}
\hline & & & Estimate \\
\hline VAR00001 & $<---$ & Induction &, 584 \\
\hline VAR00008 & $<---$ & Induction &, 586 \\
\hline VAR00009 & $<---$ & Induction &, 510 \\
\hline VAR00012 & $<---$ & hypothetical &, 772 \\
\hline VAR00014 & $<---$ & hypothetical &, 829 \\
\hline VAR00015 & $<---$ & hypothetical &, 694 \\
\hline VAR00019 & $<---$ & Empirical &, 920 \\
\hline VAR00018 & $<---$ & Empirical &, 762 \\
\hline VAR00017 & $<---$ & Empirical &, 711 \\
\hline VAR00020 & $<---$ & Deduction &, 593 \\
\hline VAR00021 & $<---$ & Deduction &, 690 \\
\hline VAR00023 & $<---$ & Deduction &, 624 \\
\hline
\end{tabular}

The result of confirmatory factor analysis can be given as follows in Figure 9: 


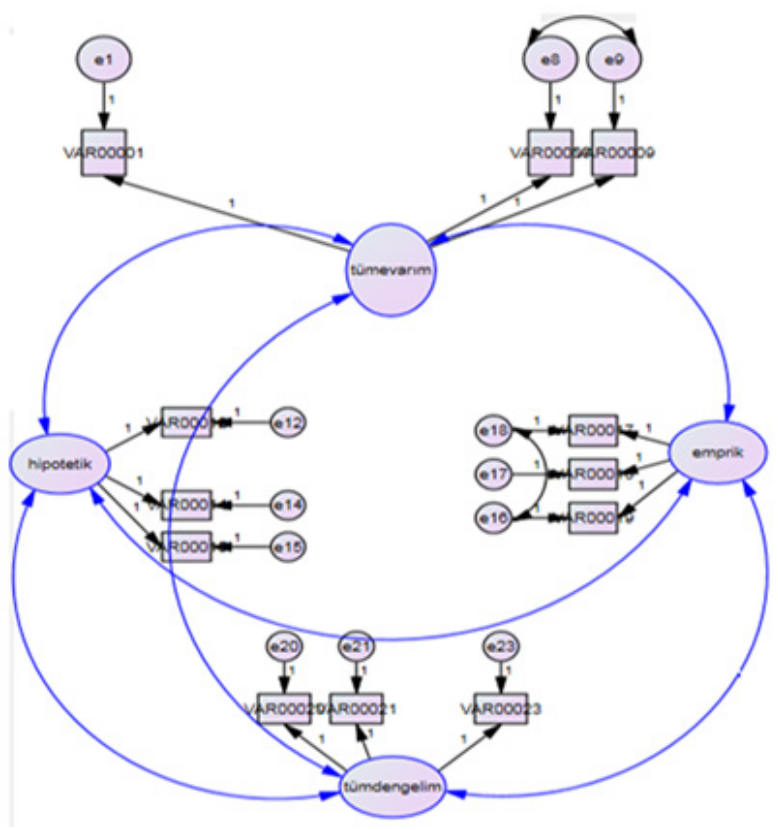

Figure 9. The structure of the confirmatory factor analysis

\section{Conclusions}

The results of these analyzes are given below.

- The total variance explained by four factors according to the eigenvalue scale in the developed reasoning style scale is $42 \%$. As a result of varimax rotation, the factor loadings of the substances varied between 0.480 and 0.726 .

- Determined factors were named as im induction "," hypothetical", "empric" and "deductive" respectively.

- For the whole scale, cronbach $\alpha \mathrm{T}=, 788$ and the cronbach $\alpha$ coefficients for each sub-dimension found to be over 0.70 indicating that the scale and the sub-dimensions of the scale are consistent within themselves.

- Differences in all groups were found to be statistically significant $(p<.001)$ in the discriminant analysis in terms of factors, indicating that the subscale and total scores of the scale were distinguishable.

- As a result of the correlation analysis conducted to determine the relationship between factors, a significant positive relationship among all factors shows that they are in the same structure but low relationships indicates that they are separate to the some extend that is compatible with scales having factor structure.

In the light of all these explanations, it can be said that this scale for determining the reasoning styles of the students has reliable results in terms of the validity and reliability tests. The scale can then be used to determine reasoning styles.

\section{Suggestions}

The Reasoning Styles scale developed in this research can be used in many ways.

Firstly, it can be used to evaluate reasoning skills and tendencies of the students in every grade. Educational materials prepared based on reasoning styles can enrich the content of the courses and provide more elaborated courses to enhance the thinking and reasoning skills of the students.

Secondly, reasoning styles scales can be used in many different researches in different designs and different samples. Reasoning styles are at least conceptually thought to be related with many cognitive and affective skills such as critical thinking, problem solving or motivation. Whether or not there are empirical correlations among those variables can be useful for preparing courses based on scientific evidence as well as proposing more healthy recipes for educational endeavors.

Thirdly, reasoning is very core concept at the hearth of any discipline. Therefore, it is very important to investigate reasoning styles for the improvement of the educational and scientific base of every discipline. Additionally, thinking skills are of having significance for information age. Information pollution is one of the important problems of our age and it is important to select "the best information" based on "the best reasoning" in fruitful ways. Therefore, reasoning styles gain importance for 21'th century skills where the thinking and reasoning skills are preferred rather than memorization or repetition of previous information in a mechanistic way. Finally, humans will need reasoning skills as never before in which artificial intelligence technologies will emerge. Although it is very difficult to predict whether or not artificial reasoning is possible, it can be foreseen that humans need more those skills in order not to get drowned by the huge amount of information surrounding them.

\section{REFERENCES}

[1] Arslan, Ç. Göcmencelebi, Ş. İ. Tapan, M. S (2009). Learning and reasoning styles of pre service teachers': inductive or deductive reasoning on science and mathematics related to their learning style, Procedia Social and Behavioral Sciences (1), 2460-2465

[2] Atakan, Ş. S. (2016). Düzenleyici Odaklar Ölçeklerinin Kavramsal ve Ampirik Olarak İncelenmesi, Tüketici ve Tüketim Araştırmaları Dergisi, Cilt 8 Sayı 1, 1-27.

[3] Bueno, O. (2012). Styles of reasoning: A pluralist view, Studies in History and Philosophy of Science 43, 657-665

[4] Buğday, E. B. (2015). Bilinçli Tüketici Ölçeği Geliştirme Çalışması,Yayımlanmamış Doktora Tezi, Hacettepe Üniversitesi / Sosyal Bilimler Enstitüsü / Aile ve Tüketici Bilimleri Anabilim Dalı, Ankara. 
[5] Ceyhan, E., \& Namlu, A. G. (2000).Bilgisayar kayg1 ölçeği (BKÖ): Geçerlik ve güvenirlik çalışması. Anadolu Üniversitesi Eğitim Fakültesi Dergisi, 10(2), 77-93.

[6] Duran, V. (2019). Öğretmen Adaylarının Akıl Yürütme Stilleri, Bilişsel Çarpıtmaları Ve Eleştirel Düşünme Eğilimlerinin İncelenmesi (Ondokuz Mayıs Üniversitesi Eğitim Fakültesi Örneği), Yayımlanmamış Doktora Tezi, Gazi Üniversitesi / Eğitim Bilimleri Enstitüsü / Eğitim Programları ve Öğretimi Anabilim Dalı / Eğitim Programları ve Öğretim Bilim Dalı, Ankara

[7] Duran, V. Özer, B. (2017). Investigation of The Reasoning Styles of The University Students, Disiplinlerarası Eğitim Araştırmaları Dergisi, (1), 1

[8] Duran, V. (2014). Öğretmen Adaylarının Hipotetik-Yaratıcı Akıl Yürütme Becerilerinin, Bilimsel Epistemolojik İnançları, Öğrenme Stilleri Ve Demografik Özellikleri Açısından İncelenmesi, Yayımlanmamış Yüksek Lisans Tezi, Muğla Sitkı Koçman Üniversitesi / Eğitim Bilimleri Enstitüsü / Eğitim Programları ve Öğretimi Anabilim Dalı / Eğitim Programları ve Öğretim Bilim Dal1, Muğla

[9] Dunbar, K. ve Fugelsang, J. (2005), Scientific Thinking and Reasoning, The CambridgeHandbook Of Thinking and Reasoning, 23 Temmuz 2014 tarihinde http://www.utsc.utoronto.ca/ dunbarlab/pubpdfs/Cam bridgehandbook 2005.pdf. adresinden ulaşılmıştır.

[10] Field, A. (2002). Discovering Statistics Using SPSS. Sage Publications Ltd., UK: London

[11] Kamer, V. (2014). İnformel mantık açısından 'Akıl yürütme' kavramı üzerine bir araştırma, Yayımlanmamış Doktora Tezi, İstanbul Üniversitesi / Sosyal Bilimler Enstitüsü / Felsefe Anabilim Dalı, İstanbul

[12] Lawson, A.E. (1995) Science Teaching and Development of Thinking. Belmont, CL: Wadsword Publishing Company, New York.

[13] Lawson, A.E. (2000). The Generality of Hypothetico-Deductive Reasoning: Making Scientific Thinking Explicit, The American Biology Teacher, 62/7, 482.

[14] Otrar, M. Argın,F.S. (2015). Öğrencilerin Sosyal Medyaya İlişkin Tutumlarını Belirlemeye Yönelik Bir Ölçek Geliştirme Çalışması, Eğitim ve Öğretim Araştırmaları Dergisi, Cilt: 4 Sayı: 1 Makale No: 37, 391-403.

[15] Tavşancıl, E. (2010). Tutumların Ölçülmesi ve SPSS ile Veri Analizi. Ankara: Nobel Yayın Dağıtım.

[16] Tekin, H. (1993). Eğitimde Ölçme ve Değerlendirme. Ankara: Yarg1.

[17] Tezbaşaran, A.A. (1996). Likert tipi ölçek geliştirme kılavuzu. Ankara: TPD Yayınları. Turgut, M. F. (1997). Eğitimde Ölçme ve Değerlendirme Metotları. Ankara: Gül Yayınevi.

[18] Stranieri, Andrew \& Zeleznikow, John \& Yearwood, John. (2001). Argumentation structures that integrate dialectical and non-dialectical reasoning. The Knowledge Engineering Review. $16.331 \quad$ - 348. $10.1017 / \mathrm{S} 0269888901000248$.

[19] Paul, R.W. ve Elder, L. (2002). Critical Thinking Tools
For Taking Charge of Your Professional and Personal Life, Prentice Hall, New Jersey 